\title{
SYNTHESIS OF THE LIGAND (Z)-2-(3-METHOXYPHENYLAMINO)-4-OXO-4-PHENYLBUT-2-ENOIC ACID AND ITS ANTIFUNGAL ACTIVITY AGAINST THE WOOD STAIN FUNGI MUCOR PLUMBEUS
}

\author{
C. PAZ ${ }^{1 *}$, D. CAJAS-MADRIAGA', C. TORRES 3 , Y. MORENO', M. J. FERNÁNDEZ', \\ J. BECERRA AND M. SILVA ${ }^{1}$

\begin{abstract}
${ }^{1}$ Laboratorio de Química de Productos Naturales, Facultad de Ciencias Naturales y Oceanográficas, Universidad de Concepción, Chile
${ }^{2}$ Fac. Cs. Químicas-Centro de Biotecnología, Universidad de Concepción, Chile

${ }^{3}$ Laboratorio de Genómica y Biodiversidad (LGB), Departamento de Ciencias Naturales, Universidad del Biobio, Chillán, Chile
\end{abstract} \\ (Received: August 6, 2012 - Accepted: January 30, 2013)
}

\begin{abstract}
The ligand (z)-2-(3-methoxyphenylamino)-4-oxo-4-phenylbut-2-enoic acid and its Ni (II) complex were synthesized and their antifungal activity against the fungi wood stain Mucor plumbeus was evaluated. The ligand displayed fungostatic activity while the Ni (II) complex exhibited antifungal activity with a MIC of $50 \mu \mathrm{g} / \mathrm{mL}$, moreover the copper complex did not showed biocide activity.
\end{abstract}

Keywords: wood stain fungi, Mucor plumbeus, Ni-complex.

\section{INTRODUCTION}

In the last three decades there has been an increase in sustainable forest plantations in the central-southern zone of Chile. More than $40 \%$ of the arable land is apt for forest soils, this has allowed the development of a dynamic forestry sector and industrial basis through monospecific plantations of forest ${ }^{1}$, which corresponds to 2.4 million hectares of plantations of exotic species of fast-growing eucalyptus and Pinus genera. The forest industry consequently represents $3.1 \%$ of the gross domestic product and is the second most important economic activity after mining ${ }^{2}$. For this reason, the damages caused by the fungi stainers of processed wood become one of the risk factors most relevant to the forestry sector ${ }^{3}$. In this regard, the fungi strainers have been a problem without a solution, by considerably diminishing the commercial value of the sawn timber due to the appearance of unusual colours and the high risk of contamination ${ }^{4}$. It is common to find stacks of sawn timber with serious damage caused by fungi of the Ceratocystis genera ${ }^{5}$, however, in recent years new strainers have been detected, among them we find representatives of Mucor genera, of which Mucor plumbeus Bon. is one of the most common ${ }^{6}$. This fungus is characterized by forming clear light to dark olive grey colonies sized from 2 to $20 \mathrm{~mm}$ occurring on the surface of sawn timber ${ }^{7}$. Contamination affects not only the processed wood, can also affect humans, putting at risk the health of the population ${ }^{8}$. The most used products for the pathogenic control of wood are chemical synthetic-based copper salts or chlorinated phenolic compounds $^{9}$

Searching for new compounds with antifungic activity we studied the acid 4-phenyl-2,4-dioxobutanoic acid, which reported important biological activities like enzyme inhibitor of HIV-1 integrase ${ }^{10}$, in bacteria inhibits KDPG aldolase ${ }^{11}$ and derivates have shown analgesic activity ${ }^{12}$. From the 2,4-dioxobutanoic acid, we synthesized the ligand keto-enamine (z)-2-(3methoxyphenylamino)-4-oxo-4-phenylbut-2-enoic acid (L) and their Ni (II) and $\mathrm{Cu}$ (II) complexes and studied their fungicide activity in the wood stain fungi Mucor plumbeus.

\section{EXPERIMENTAL}

The ${ }^{1} \mathrm{H}-\mathrm{NMR}$ spectra were determined using a Bruker ARX 300 instrument, operating at $300.1 \mathrm{MHz}\left({ }^{1} \mathrm{H}\right)$ and $75.5 \mathrm{MHz}\left({ }^{13} \mathrm{C}\right)$. EI MS spectra were measured on Trace DSQII GC/MS-system (Axel Semrau GmbH \& Co). FT-IR-spectrometer Nicolet 6700 from Thermo Electron Corporation with the ATR-unit Smart Performer. Melting points were determined on a Melting Point SMP10 (Stuart) uncorrected. Column Chromatography was performed using Merck silica gel $60(0.063-0.200 \mathrm{~mm})$. TLC was carried out on a Merck silica gel 60 PF254. Solvents used in this study were distilled prior to use and dried over appropriate drying agents.
General synthesis

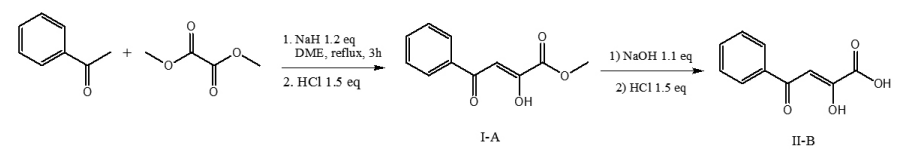

Scheme 1

(Z)-Methyl 2-hydroxy-4-oxo-4-phenylbut-2-enoate (I-A): A mixture of acetophenone $(1.0 \mathrm{~g}, 8.3 \mathrm{mmol})$ and dimethyloxalate $(1.2 \mathrm{~g}, 10 \mathrm{mmol})$ were stirred in $150 \mathrm{~mL}$ of anhydrous dimethoxyethane, then sodium hydride ( $240 \mathrm{mg}, 10 \mathrm{mmol}$ ) was added. The mixture was stirred under reflux for 4 h. The reaction was cooled and quenched with water $100 \mathrm{~mL}$ and $\mathrm{HCl}$ until $\mathrm{pH}$ 2. The mixture was extracted 3 times with EtOAc, and the organic layer was evaporated in vacuo. The compound precipitated as a white solid (1.49 g, 84\%). ${ }^{1} \mathrm{H}-\mathrm{NMR}\left(\mathrm{CDCl}_{3}, 300 \mathrm{MHz}\right) \mathrm{ppm}: 3.94(3 \mathrm{H}, \mathrm{s}) ; 7.10(1 \mathrm{H}, \mathrm{s}) ; 7.50$ $(2 \mathrm{H}, \mathrm{m}) ; 7.61(1 \mathrm{H}, \mathrm{m}) ; 8.00(2 \mathrm{H}, \mathrm{m}), 15.83(1 \mathrm{H}, \mathrm{s}$, interchangeable $) .{ }^{13} \mathrm{C}-\mathrm{NMR}$ $\left(\mathrm{CDCl}_{3}, 75 \mathrm{MHz}\right)$ ppm: $55.4 ; 99.4 ; 127.5 ; 129.2 ; 130.2 ; 135.2 ; 162.6 ; 169.1$; 190.8. EI-MS: $206 \mathrm{~g} / \mathrm{mol}$

(Z)-2-Hydroxy-4-oxo-4-phenylbut-2-enoic acid (II-B): Hydrolysis of I-A $(1.0 \mathrm{~g}, 4.9 \mathrm{mmol})$ was carried out with $\mathrm{NaOH}(194 \mathrm{mg}, 4.9 \mathrm{mmol})$ in $20 \mathrm{~mL}$ of water and stirred at $50^{\circ} \mathrm{C}$ for $15 \mathrm{~min}$. The reaction was filtered and the reaction mixture was extracted three times with $10 \mathrm{~mL}$ of ethyl acetate. The water layer was acidified with $\mathrm{HCl}$ until $\mathrm{pH} 2$. The product precipitated as a white solid, then filtered off and dried $(752 \mathrm{mg}, 80 \%), \mathrm{mp}=160^{\circ} \mathrm{C}$. ${ }^{1} \mathrm{H}-\mathrm{NMR}\left(\mathrm{CDCl}_{3}, 300\right.$ $\mathrm{MHz})$ ppm: $6.75(1 \mathrm{H}, \mathrm{br}) ; 7.52(2 \mathrm{H}, \mathrm{m}) ; 7.53(1 \mathrm{H}, \mathrm{d}, \mathrm{J}=4.2 \mathrm{~Hz}) ; 7.87(2 \mathrm{H}, \mathrm{d}$, $\mathrm{J}=4.5 \mathrm{~Hz}) .{ }^{13} \mathrm{C}-\mathrm{NMR}\left(\mathrm{CDCl}_{3}, 75 \mathrm{MHz}\right)$ ppm: $98.0 ; 127.5 ; 128.0 ; 128.4 ; 128.9$; 133.0; 135.4; 163.8. EI-MS: $192 \mathrm{~g} / \mathrm{mol}$

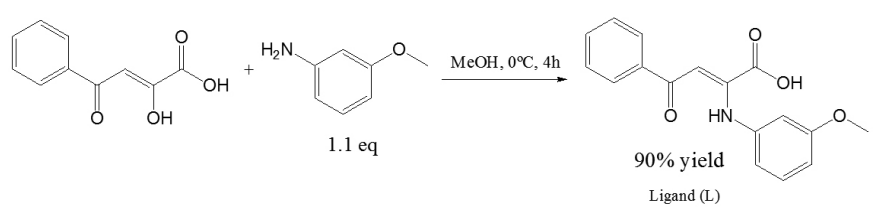

Scheme 2

(z)-2-(3-methoxyphenylamino)-4-oxo-4-phenylbut-2-enoic acid (L): Condensation of II-B (700 mg, $3.6 \mathrm{mmol})$ with 3-methoxy aniline (493 mg, $4.0 \mathrm{mmol}$ ) was carried out in methanol $50 \mathrm{~mL}$ at $0{ }^{\circ} \mathrm{C}$ by $4 \mathrm{~h}$. The product precipitated as a yellow solid, $962 \mathrm{mg}, 90 \%$ yield, $\mathrm{mp}=168-169^{\circ} \mathrm{C} .{ }^{1} \mathrm{H}-\mathrm{NMR}$ (DMSO-d6, $300 \mathrm{MHz})$ ppm: $3.73(3 \mathrm{H}, \mathrm{s}) ; 6.12(1 \mathrm{H}, \mathrm{s}) ; 6.70(2 \mathrm{H}, \mathrm{m}) ; 6.79(1 \mathrm{H}$, d, J=2Hz); $7.22(1 \mathrm{H}, \mathrm{t}, \mathrm{J}=8.1 \mathrm{~Hz}) ; 7.42(1 \mathrm{H}, \mathrm{m}) ; 7.48(2 \mathrm{H}, \mathrm{m}), 7.55(1 \mathrm{H}, \mathrm{d}, \mathrm{J}=$ $7.2 \mathrm{~Hz}) ; 7.92(2 \mathrm{H}, \mathrm{d}, \mathrm{J}=7.2 \mathrm{~Hz}) ; 12.22(1 \mathrm{H}, \mathrm{s}) .{ }^{13} \mathrm{C}-\mathrm{NMR}$ (DMSO-d6, $75 \mathrm{MHz}$ ) ppm: $55.1 ; 9.44 ; 106.3 ; 110.2 ; 112.9 ; 127.1 ; 128.7 ; 129.9 ; 131.8 ; 138.7 ; 140.5$; $154.9 ; 159.9 ; 165.7 ; 1889.5$. IR-KBr $\left(\mathrm{cm}^{-1}\right): 3219 \mathrm{NH} ; 1604 \mathrm{C}=\mathrm{O} ; 1575 \mathrm{~N}=\mathrm{O}$. 


\section{Complex synthesis}

The complexes of $\mathrm{Ni}(\mathrm{II})$ and $\mathrm{Cu}(\mathrm{II})$ were obtained by reflux of $300 \mathrm{mg}$ $(1.0 \mathrm{mmol})$ of the ligand, dissolved in $30 \mathrm{ml}$ of methanol, with a solution of 0.5 equivalents of the corresponding metal salt, $\mathrm{NiCl}_{2} \cdot 6 \mathrm{H}_{2} \mathrm{O}(119 \mathrm{mg}, 0.5 \mathrm{mmol})$ or $\mathrm{CuSO} 4 \cdot 5 \mathrm{H}_{2} \mathrm{O}(125 \mathrm{mg}, 0.5 \mathrm{mmol})$ in $15 \mathrm{ml}$ water was added dropwise with continuous stirring. The mixture was stirred under reflux for $6 \mathrm{~h}$. The solvent was removed in vacuum obtaining a green solid that was washed with ethyl acetate three times, followed by cold methanol-water ratio 1:1. The complex was then dried in vacuum desiccators.

Ni-Complex: green solid, descomposition over $210^{\circ} \mathrm{C}$. IR-KBr $\left(\mathrm{cm}^{-1}\right)$ : $1591 \mathrm{C}=\mathrm{O} ; 1575 \mathrm{~N}=\mathrm{O}$.

\section{Fungus isolation}

Mucor plumbeus was isolated from wood stain collected in a sawmill near Concepción, VIII Region, Chile (36 $\left.46^{\circ} \mathrm{S}-7^{\circ} 56^{\prime} \mathrm{O}\right)$. Infected wood samples were suspended in steril water, and dilutions of this suspention were streaked out onto YMG agar augmented with $200 \mathrm{mg} \mathrm{1-1}$ of streptomycin, at $\mathrm{pH} 5.5$ and incubated at $22^{\circ} \mathrm{C}$ by 7 days, procedure repeated 3 times till pure colonies grow up in the plate as gray mycelium which was verified by microscopic examination ${ }^{13}$. This strain has been deposited at the collection of the Laboratory of Natural Products Chemistry of University of Concepción, Chile (accession number LQMP-001).

\section{Fungus Identification}

In order to validate the morphological identification of Mucor plumbeus strain, it was amplified the $28 \mathrm{~S}$ nuclear ribosomal large subunit rRNA (LSU) using Lr0R/Lr6 primer combination that covers D1, 28S Ribosomal RNA gene, D2, and D3 regions ${ }^{14}$. DNA was extracted from fruit bodies using the E.Z.N.A. fungal DNA MiniKit (Omega-Biotek). PCR reactions were performed using LR0R (5'-gtacccgctgaacttaagc-3') as forward primer and LR06 (5' -cgccagttctgcttacc-3') as reverse primer. Each reaction was conducted in a $15 \mu \mathrm{L}$ volume containing 30-50 ng of DNA, $1 \mathrm{X}$ of PCR buffer, $2 \mathrm{mM}$ $\mathrm{MgCl}_{2}, 0.1 \mu \mathrm{M}$ of each dNTP, $0.5 \mu \mathrm{M}$ of forward and reverse primers, and $1 \mathrm{U}$ of Taq DNA polymerase. PCR amplification was carried out with an initial denaturation of $4 \mathrm{~min}$ at $94^{\circ} \mathrm{C}$, and then 35 cycles of $30 \mathrm{~s}$ at $94^{\circ} \mathrm{C}, 60$ $\mathrm{s}$ at $50^{\circ} \mathrm{C}$ and $60 \mathrm{~s}$ at $72^{\circ} \mathrm{C} \mathrm{s}$, followed by a final step of $5 \mathrm{~min}$ at $72^{\circ} \mathrm{C}$. After PCR purification and sequencing (both directions) by Macrogen sequencing service (Seoul, Korea), analyses of sequences were edited using Genious v5.4 software ${ }^{15}$. The sequence of $M$. plumbeus 28S Ribosomal RNA gene was analyzed with BLAST (Basic Local Alignment Search Tool) (http://blast.ncbi. nlm.nih.gov/Blast.cgi) to determine the percentage of maximal identity with the sequences of the global database. Finally, the sequence obtained from the present study was deposited in GenBank with the code BankIt1532924 Seq1 JX123134.

\section{Antifungal activity determination}

\section{Agar diffusion test}

Antifungal activity of $\mathrm{L}$ and their $\mathrm{Ni}(\mathrm{II})$ and $\mathrm{Cu}(\mathrm{II})$ complexes was qualitatively evaluated by diffusion test in agar YMG. Plates were inoculated with a spore concentration of $10^{6}$ spores $/ \mathrm{mL}$ of M. plumbeus. Paper disks (6 $\mathrm{mm}$ ) were impregnated with $200 \mu \mathrm{g}$ of ligand $\mathrm{L}, \mathrm{Ni}(\mathrm{II})$ complex and $\mathrm{Cu}(\mathrm{II})$ complex. As positive control was used antiblue 375 and DMSO as negative control (solvent). Plates were incubated at $22^{\circ} \mathrm{C}$ by 21 days ${ }^{16}$.

\section{Microtitre plate test}

The minimal inhibitory concentration (MIC) was determined following the method described by Sarker et al $2007^{17,18}$. Microplates were cultivated in liquid media YMG, pH 5.5 and inoculated with $25 \mu \mathrm{L}$ of solution $10^{5} \mathrm{FCU} /$ $\mathrm{mL}$ per well. Solutions of $\mathrm{L}$ and $\mathrm{Ni}(\mathrm{II})$ complex were added in decreasing concentrations from $400 \mu \mathrm{g} / \mathrm{mL}$ to $3,2 \mu \mathrm{g} / \mathrm{mL}$. Plates were incubated at $22^{\circ} \mathrm{C}$ by 21 days. The activity was evaluated by spectroscopic methods at $450 \mathrm{~nm}$ in Epoch $^{\mathrm{TM}}$ (BIOTEK $\left.{ }^{\circledR}\right)$ spectrophotometer recording the absorbance of each well after incubation and correcting the blank control. Each sample was analyzed in triplicate.

\section{RESULTS AND DISCUSSION}

The synthesized compound (z)-2-(3-methoxyphenylamino)-4-oxo-4phenylbut-2-enoic acid (L), displays a conjugate system, enaminoketone, give rise to intramolecular hydrogen bonding. The IR spectrum of $L$ exhibits bands at 3220 and $1604 \mathrm{~cm}^{-1}$ for the $\mathrm{NH}$ and $\mathrm{CO}$ stretching modes, respectively. The ligand conjugate system undergoes a tautomeric equilibrium (keto-enol//imineenamine) as is reported in other similar systems ${ }^{19-22}$, showed in the scheme 3 and 4 .<smiles>[2H]N/C(=C\C(=O)c1ccccc1)C(=O)O</smiles>

$\mathrm{Z}$ configuration<smiles>N/C(=C/C(=O)c1ccccc1)C(=O)O</smiles>

E configuration
Scheme 3

The ${ }^{1} \mathrm{H}$ NMR spectrum of this compound in DMSO- $\mathrm{d}_{6}$ at $20^{\circ} \mathrm{C}$ exhibits sharp signals characteristic of a single conformer $(\mathrm{Z})$. Therefore $\mathrm{L}$ presents an intramolecularly $\mathrm{H}$-bonded $Z$ configuration ${ }^{23}$.

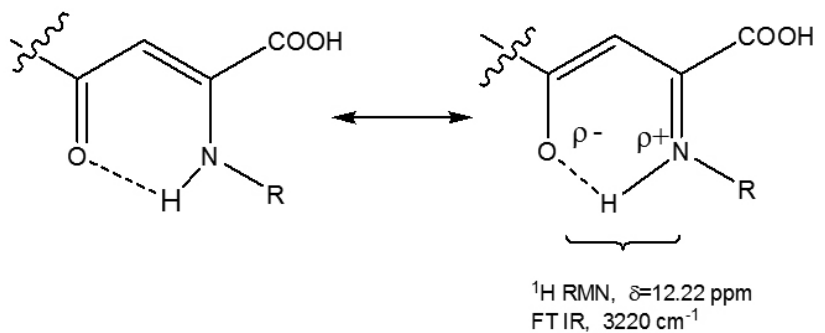

Scheme 4

With this in mind, for the reaction between the ligand and nickel (II), it has been postulated the following complex (Scheme 5).

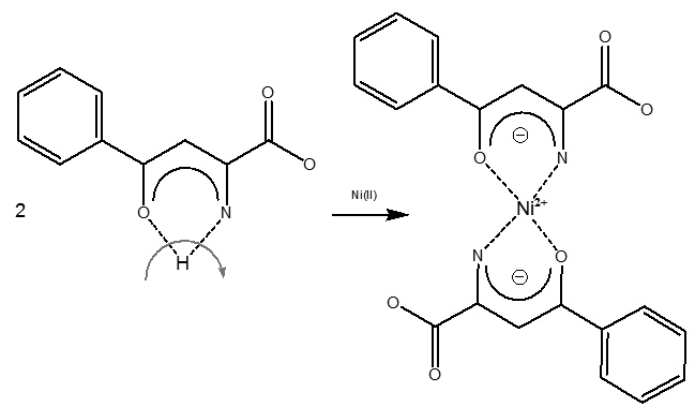

Scheme 5

The infrared spectrum does not have a normal N-H band, because the system has been deprotonated. Instead the $\mathrm{CO}$ stretching mode has been shifted to $1591 \mathrm{~cm}^{-1}$ due to the $\mathrm{Ni}-\mathrm{O}=\mathrm{C}$ coordination. The apical position could be occupied by a molecule of oxygen from the carboxylate group of a neighboring ligand; if possible then it will generate an infinite chain (Scheme 6).

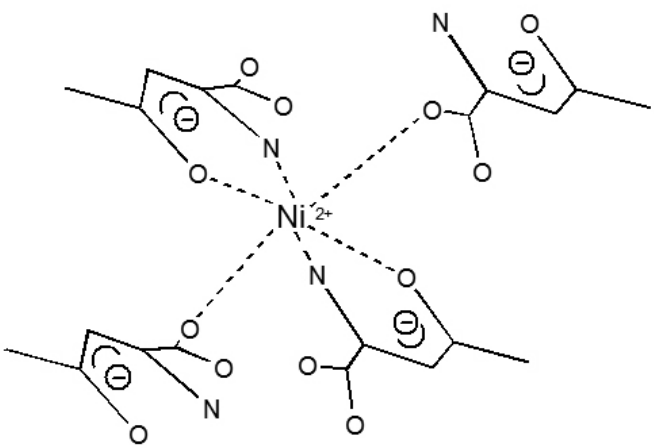

Scheme 6

The interpretation of infrared to the complex is difficult because the metal ion coordination causes displacement of the bands; and it is possible that one of the tautomeric forms predominates over the other ${ }^{24}$. In spite of this, an assignation for the bands is proposed, Table 1 . 
Table 1: Infra-red analysis for Ni(II) complex.

\begin{tabular}{|c|c|c|}
\hline Molecular vibration & Ligand $\left(\mathrm{cm}^{-1}\right)$ & Complex $\left(\mathrm{cm}^{-1}\right)$ \\
\hline $\mathrm{N}-\mathrm{H}$ & 3219 & - \\
$\mathrm{C}=\mathrm{O}$ & 1604 & 1591 \\
$\mathrm{C}=\mathrm{N}$ & 1575 & 1575 \\
\hline
\end{tabular}

\section{Fungal strain}

The microscopic analysis of the strain is coincident with the description for Mucor species presented by Schipper ${ }^{7}$ in 1976; colony varying from 2-20 $\mathrm{mm}$ in height, Mouse Gray, Deep Mouse Gray or Light Olive Gray colour; sporangiophores branching in a sympodial and in a monopodial fashion (Fig. 1A), up to $21 \mu \mathrm{m}$ in diam., constricted and infrequently recurved below sporangia, with slightly incrusted walls. Columellae pyriform, obovoid on a truncate base, ellipsoidal to cylindrical-ellipsoidal, with incrusted walls that rupture at maturity (Fig. 1B). The analysis of the RNA sequence fragment 972 $\mathrm{pb}$, performed in BLAST, confirmed the identity of the fungus as M. plumbeus (BankIt1532924 Seq1 JX123134) with a one hundred percent match to M. plumbeus strain available from Genbank database (JN938896 ${ }^{25}$.

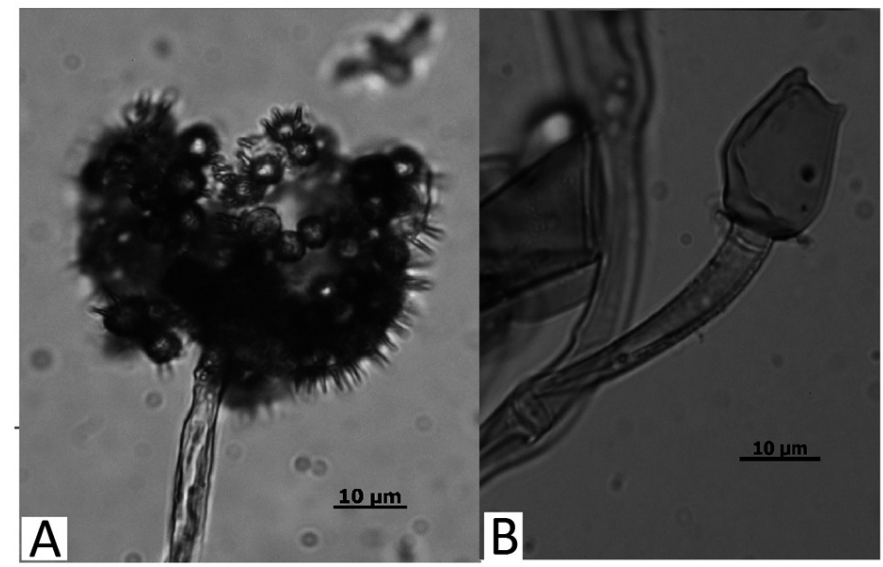

Figure 1. Microscopic features of Mucor plumbeus. A) Sporangiophoro and spores growing on YMG agar. B) Pyriform columella wituout spores.

\section{Antifungal activity}

Qualitative agar diffusion test of Cu-Complex, Ni-Complex, Ligand and control were carried out against the native fungus M. plumbeus LQMP-001. The Ni complex displayed strong antifungal activity at concentration of 200 $\mu \mathrm{g} / \mathrm{disk}$, evidenced with a halo of $31 \mathrm{~mm}$ around disk after 21 days, figure $2 \mathrm{~A}$ (1). The $\mathrm{Cu}$ complex did not show inhibitory halo at concentration of $200 \mu \mathrm{g} /$ disk, figure $2 \mathrm{~A}(2)$.

The ligand (L) did not show antifungal activity at concentration of $200 \mu \mathrm{g} /$ disk, but it delayed the mycelial growth in the first $72 \mathrm{~h}$, suggesting that it has fungostatic activity over M. plumbeus LQMP-001, figure 2B (2). The positive control, antiblue 375 , displayed an inhibitory halo of $36 \mathrm{~mm}$ around disk at concentration of $200 \mu \mathrm{g} /$ disk, figure 2B (1).

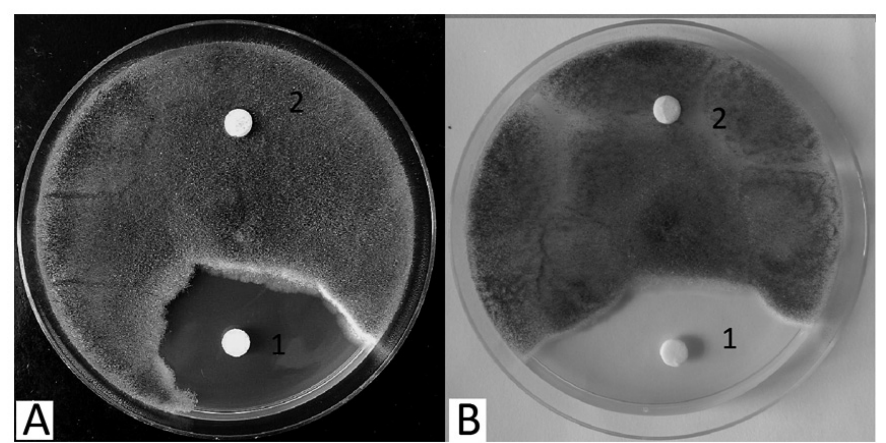

Figure 2. Antifungal activity against Mucor plumbeus at $200 \mu \mathrm{g} / \mathrm{disk}$ after 21 days. A) Complex LNi (1) and complex LCu (2). B) Positive Control, Antiblue 375 (1) and ligand (2).
Further Quantitative assays against the native fungus M. plumbeus LQMP001 by microtitre plate test, $\mathrm{n}=3$, determinate than the $\mathrm{Ni}$ complex has a minimal inhibitory concentration MIC, of $50 \mu \mathrm{g} / \mathrm{mL}$. The Cu-complex has a MIC higher than $200 \mu \mathrm{g} / \mathrm{mL}$. The control antiblue 375, showed a MIC of $10 \mu \mathrm{g} / \mathrm{mL}, \mathrm{n}=3$.

\section{CONCLUSIONS}

We have synthesized and evaluated in vitro the antifungal activity of the ligand (z)-2-(3-methoxyphenylamino)-4-oxo-4-phenylbut-2-enoic acid and its metal complex's of nickel and cupper against the wood stain fungus Mucor plumbeus LQMP-001. According to the in vitro results, the ligand displays fungostatic activity. The incorporation of $\mathrm{Ni}$ to the ligand molecule, formed a $\mathrm{Ni}(\mathrm{II})$ complex with antifungal activity, MIC of $50 \mu \mathrm{g} / \mathrm{mL}$. Furthermore, the $\mathrm{Cu}$ (II) complex did not have bioactivity at concentration of $200 \mu \mathrm{g} / \mathrm{mL}$ or lower. The Ni complex could be a promising candidate as new antifungal agent for control of wood stain fungi.

The mechanism resistance to organometallic compounds of these metals is still unknown ${ }^{26}$. Furthermore, several studies reported that the organometallic compounds of the divalent cations are more toxic than their metallic forms, particularly when compared to their own inorganic equivalents ${ }^{27,28}$.

\section{ACKNOWLEDGEMENTS}

Authors would like to thank the financial support from the Project Fondecyt 3130378, Project Basal PFB-27 (PCS-009), Universidad de Concepción and CONICYT for of its Doctoral Scholarship Program.

\section{REFERENCES}

1. R. Juacida, S. Benedetti. BOSQUE. 18, 87, (1997)

2. Instituto Forestal (INFOR). El sector forestal chileno en una mirada. Santiago, Chile, 2005; pp. 68

3. I. Vives, S. Ide, H. Peredo. BOSOUE. 25, 79, (2004)

4. C. Behrendt, R. Blanchette, R. Farrel. Phytopathology. 85, 92, (1995)

5. H. Butin and H. Peredo in Hongos parásitos en coníferas del sur con especial referencia a Chile. Biblioteca Mycologica. Band 101. J. Cramer. pp 100, 1986

6. L. Giordano, P. Gonthier, G.C. Varese, L. Miserere, G. Nicolotti. Fungal Diversity. 38, 69, (2009)

7. M. Schipper. Studies in Micology $\mathrm{N}^{\circ} 12$. Institute of the Royal Netherlands, Academy of Arts and Sciences. Netherland. pp 40. 1976

8. J. Webster and R. Weber. Introduction to fungi. Cambridge, $3^{\text {rd }}$ edition. pp 841. 2007

9. P. Montes, H. Peredo, D. Lanfranco, S. Ide and H. Dolz. BOSQUE. 22, 85, (2001)

10. M. Sechi, F. Carta, L. Sannia, R. Dallocchio, A. Dessi, R. Al-Safi, N. Neamati. Antiviral Research., 81, 267, (2009)

11. R. Braga, L. Hecquet, C. Blonski. Bioorganic and Medicinal Chemistry. 12, 2965, (2004)

12. E. Koz'minykh, A. belyaev, E. Berezina, V. Koz'minykh, R. Makhmudov, T. Odegova, Pharmaceutical Chemistry Journal. 36, 643, (2002)

13. M. Carvalho, S. Tavaresa, J. Medeirosa, O. Núñez, H. Gallart-Ayala, M. Leitão, M. Galceran, A. Hursthouse, C. Silva. Journal of Hazardous Materials. 198, 133, (2011)

14. L. Tedersoo, T. Suvi, T. Jairus, S. Kõljalg. Environmental microbiology. 10, 1189, (2009)

15. A.J. Drummond, B. Ashton, S. Burton, M. Cheung, A. Cooper, J. Heled, R. Moir, S. Stones-Havas, S. Sturrock, T. Thierer, Geneious 5.4, Avalaible from: http://www.geneious.com/. (2011)

16. S. Suzuki, T. Murayama, Y. Shiono. Phytochemistry. 66, 2329, (2005)

17. D. Sarker, L. Nahar, Y. Kumarasamy. Methods. 42, 321, (2007)

18. Y. Morera, J. Torres-Rodríguez, T. Jiménez. Rev Iberoam Micol. 22, 105, (2005)

19. J. Lee, T. Lee, L. Chang, C. Lin, H. Lee, L. Hung, A. Datta, J. Huang, Journal of Molecular Structure, 929, 207, (2009)

20. V. Rybalkin, L. Popova, A. Dubonosov, E. Shepelenko, Y. Revinskii, V Bren, V. Minkin, Russian Journal of Organic Chemistry, 37, (2001)

21. X. Yang, J. Liu, F. Zhao. Journal of Fluorine Chemistry. 125, 415, (2004)

22. M. Habibi, H. Loghmani-Khouzani, M. Mirmohammad Sadeghi, R. Harrington, W. Clegg, M. Ghorbani. Analytical Sciences, 22, (2006)

23. A. Dixit, K. Reddy, A. Deshmukh, S. Rajappa, B. Ganguly, J. Chandrasekhar. Tetrahedron. 51, 1437, (1995) 
24. J. Ledbetter. The Journal of Physical Chemistry. 81, (1977)

25. C.L. Storch, K.A. Seifert, S. Huhndorf, V. Robert, J.L. Spouge, C.A. Levesque, W. Chen, Fungal Barcoding Consortiuma. Proceedings of the National Academy Science, USA. 109, 6241, (2012)
26. H.N. Dietric. Plasmid. 27, 17, (1992)

27. K. Fent, Crit. Rev. Toxicol. 26, 1, (1996)

28. M. Anderiana, S.V. Avery, M.A. Zoroddu, G.M. Gadd, FEMS Microbiol. Lett. 167, 321, (1998) 